\title{
Perceived Political Economy of Strikes on Selected Communities in Ondo and Ekiti States, South Western Nigeria
}

\author{
Fasunwon Adebayo Folorunso, $\mathrm{PhD}^{1}$, Ariyo Ojo Olawale ${ }^{2 *}$ \\ ${ }^{1}$ Department of Political Science and Public Administration, Adekunle Ajasin University, Akungba Akoko, Ondo State Nigeria \\ ${ }^{2}$ Ekiti State University, Ado Ekiti, Nigeria
}

DOI: $\underline{10.36348 / \text { sjhss.2020.v05i08.009 }}$ | Received: 16.08 .2020 | Accepted: 23.08 .2020 | Published: 29.08 .2020

*Corresponding author: Ariyo Ojo Olawale

\section{Abstract}

Industrial actions are all forms of work dissatisfaction that can manifest in several ways like absenteeism, strike, high labour turnover among others. This has posed a lot of threats to all sectors of the economy and affected Nigeria society socially, economically and politically. Two theoretical postulations were used to investigate the perceived causes and effects of industrial actions in South West Nigeria. Survey research which involved 400 respondents from four randomly selected local governments was employed in the study. Data, which were sourced from both primary and secondary sources, were analysed using quantitative and qualitative methods. From the findings, the respondents revealed that hike petroleum price $(85.3 \%)$, poor working conditions $(66.3 \%)$, labour union interest $(72.6 \%)$, members' welfare $(64.2 \%)$ and failure of management to keep to agreement $(73.7 \%)$ were some of the factors responsible for industrial actions in Nigeria. Also, the respondents confirmed that undeveloped economy (70.6\%), political stability $(53.7 \%)$, development of entrepreneurial skills $(66.3 \%)$, improved government administrative efficiency $(70.5 \%)$, brain drain $(80 \%)$, and increased poverty $(60 \%)$ were the perceived outcomes of industrial actions on Nigeria political economy. On the efficacy of strike actions, respondents affirmed that labour union objectives are usually attained during strike (64.2\%), and there were increases on wage labour $(65.3 \%)$. Based on the findings, strike favours the workers, and negatively affects the nation and government in the long run. Thus, it was recommended that, there is need for stable labour-management relations between the government, industries and employees that will enhance a good bargaining environment. Also, there is need to improve on minimum wage policy of the government for the employees so as to improve the welfare of the employees and reduce the incidences of strike actions.

Keywords: Strike, causes, labour, wage, poverty, government.

Copyright @ 2020: This is an open-access article distributed under the terms of the Creative Commons Attribution license which permits unrestricted use, distribution, and reproduction in any medium for non-commercial use (NonCommercial, or CC-BY-NC) provided the original author and source are credited.

\section{INTRODUCTION}

Industrial action is a global pandemic that affect both the industrial sector, government and the citizenry. It is historically dated back to the end of the 20th dynasty, under Pharaoh Ramses III in ancient Egypt on 14 November 1152BC. The artisans of the Royal Necropolis at Deir el - Medina walked off their jobs because they had not been paid. Since then; it has been a prevalent feature of labour union across the globe [1]. Strike is considered as a temporary stoppage effected by one or more groups of workers with a view to enforcing or resisting demands or expressing grievances or supporting other workers in their demands or grievances [2].
Therefore, strike represents a great challenge to the government; both as employer and as a state. However, in Nigeria, series and frequent industrial actions have been witnessed between employees' unions and government especially between Academic Staff Union of Universities, Trade Union Congress, Petroleum and Natural Gas Senior Staff Association of Nigeria, Nigerian labour Congress, Nigerian Medical Union and the Federal or State Government [3]. While industrial conflict is bound to exist, its prevalence and re-occurrence, as in Nigeria, express the existence of unhealthy relationship between key actors in an industrial setting [4]. Adeogun [5] remarked that strike is all about grievances, actual or imagined, arising from industrial life. 
The continuous and looming strikes in Nigeria significantly explain how the government values their employees in implementing basic agreement between the State and the unions which has socio-political and economic impact on both the unions and the society. Some of the factors responsible for persistent industrial actions in Nigeria include poor infrastructural base in the workplace, low level of motivation, insecurity of jobs, policy inconsistencies and variance in management styles, breach of collective agreement [6]. While literature has specific dealt with the issue of strike actions by different segments or sectors of the economy [7, 8, 3], management of trade disputes [6], and its attendant effects on the economy [9], social changes [10] and reduces standard of education [11].

However, the extent of the literature could not foresee socio-political and economic implication of the kind of the looming strikes in the present global pandemic ravaging the world, Yet many sectors of the economy including Academic Staff Union of the University (ASUU), Medical and Health Workers Union, Petroleum and Natural Gas Senior Staff Association of Nigeria (PENGASSAN) National Association of Residential Doctors and other were also on strike instead of providing the basic fulcrum and leap ways for researches and ease Nigerians out of the global pandemic. That all the sectors of the economy are bedeviled with industrial crisis in Nigeria suggests that the wheel that is turning the nation is gradually grinding to a halt [10]. This increasing incidence of strike implies that the very fabric of the Nigerian economy is being threatened, with looming severe socioeconomic adversities with concomitant shifts in workers' bargaining power and thereby influences the likelihood of strikes [8]. Also, the tripartite negotiations between unions, employers and the state which may be considered political effects of the strike action and consequence of a rupture in the positive political exchange between unions and the state, in which the government trades goods in exchange for social consensus [12].

However, it is equally good to note that the looming industrial conflicts in Nigeria during this era of global pandemic is not a deviation from the norms in the country; the current industrial actions especially by the Academic Staff Union of Universities ASUU, Petroleum and Natural Gas Senior Staff Association of Nigeria PENGASSAN and NUPENG attest to the seamlessness of what Nigerians have been exposed to in the time past. Even the current final year students of most of the public universities would have undergone similar experiences in the time past, most of the students would have spent six years in the University for Four years Course. While both members of unions and the society at large suffer the consequences in the economic harshness, income summersault, the impacts of the industrial actions on political bizarre, organizational productivity, negotiations and strategies should be understudied by the scholars. Hence, the focus of this paper is not only to study the factors responsible for strike actions in Nigeria but also to assess the impacts of strike actions on political economy of the nation and organization's productivity.

\section{METHODOLOGY}

The study examines the perceived political economy of strike actions in selected communities in South West Nigeria. Survey research method was employed in this study. Primary data were obtained through the use of structured questionnaire, while secondary data were sourced from relevant textbooks, journals, internet, government official gazette, and others. A multistage random sampling technique was used to select respondents for this study. The first stage involved purposive selection of Ekiti and Ondo States as the studied areas. The states were selected because of the peculiarity of the economy dependence of the states to the public sector workforce. The States have one of the largest percentages of the labour force in public sectors in South West Nigeria. The second stage involved random selection of two local governments for the administration of the questionnaire in the States. The two local governments from each of the states were chosen based on the rural and urban population. Ado Ekiti and Gbonyin Local Government Areas were selected as urban and rural communities respectively in Ekiti State while Akure South and Akoko South West Local Government Areas were selected as urban and rural communities respectively in Ondo State for the administration of the questionnaire.

The last stage of the sampling was the random selection of the respondents based on their economic age (20-79years and above). 100 pieces of questionnaire were administered in each of the selected local government area. In all a total of four hundred respondents (400) were drawn across the states for this study. The data was analyzed using Chi square and correlation coefficients. However, only 380 questionnaires were retrieved and analysed in this study.

\section{LITERATURE REVIEW}

Globally, there are growing bodies of literature and evidences that showed challenges of industrial actions to the economic imbalances of the Nigeria public sector. Studies by Ojeifo [1] provide a historical and sociological account of the origin, development, causes and effects of the industrial actions in Nigeria universities' teachers. The study was limited by its usefulness in studying the prevailing conditions attached to the university teachers without examining economic viability of the environment and the government. Similar study by Wokoma [10] identifies failure in collective bargaining of the union, refusal of government to recognize the union and poor governmental policies as the causes of industrial conflicts in Nigeria. Thus, Makosa [7] aligned poor 
funding of the university system in Nigeria to decline in oil wealth accrued to the nation and the nature of political leadership in Nigeria.

Furthering the analysis of factors affecting industrial actions, Fashoyin [13] highlighted structural organization, poor decision making power, management policies and poor procedural means of bargaining are the major causes of rift between labour union and management.

A number of recent studies are based on the political and economic factors influencing strike activities. Studies by Pohl [8] shed light on industrial conflict and its influence on the economic recession in Spain. Pohl avers that if there is increase in strike motives of labour-related, then it tends to lead to staff downsizing, industrial restructuring and non-payment of wages and decrease in worker's bargaining power in times of economic downturn [8]. Pohl thoughtfully gave an insightful view of the political and economic factor influencing the strike actions in Spain but failed to examine the influence of the factors on the socioeconomic and political prosperity of the society.

Similar studies in Nigeria by Akinwotu [3]; and Okene [14] contended that failure in collective bargaining is the major causes of rift between government and the union. The studies justified it with several lackadaisical attitude of government to implement the term of agreement between the labour union and the Federal Government in Nigeria especially between the ASUU, NUPENG and the Federal Government. It is believed this has generated a lot of industrial disharmonies and conflicts between the two bodies. Corroborating this, study by Ekankumo and Konye [15] indentified poor infrastructural development, breaches in agreements, poor remunerations and poor welfare packages of the workers as some of the causes of the industrial disharmony in Nigerian teaching hospital. Meanwhile, a good bargaining strategy between the employees and the management will enhance greater productivity and performance of the organization [16] while decrease in workers' bargaining power can lead to staff downsizing and industrial restructuring [8]. Related to effects of industrial action on economic development of Nigeria, Ubeku [9] avers that industrial actions have longstanding effects on the Gross Domestic Product and result in the underdevelopment of the nation. Similar study by Longe [16] found that workplace conflict has a significant effect on performance of the manufacturing companies.

Recent study by David and Alexander [17] gave a clear view of the implication of the industrial actions on the economy of Argentina. The study avers that teachers strike actions affected school distributions, calendar imbalances, socio-economic effect on labour market including increase in unemployment, increase in probability of not working or studying, declines in skills and reduction in annual labour market earning [17]. The study is useful as it gave a clear understanding of the effects of teachers' industrial actions on the economy of Argentina which may be useful for the understanding of the socio-political and economic influences of the industrial actions on Nigeria economy. Having taken a cue from the studies cited above with relevance of most of the literature to the apparent subject of discussion on industrial action, it is crystal clear that most studies underweighted the implications of strike action on the political economy of the environment and how these factors affect the productivity of the organizations in question, this study tends to fill the gap.

\section{THEORETICAL FRAMEWORK}

The study is anchored on the Marxian political economy and institutional approach. The scholars of new institutionalism Powell and Dimargo 1991 [18]; Scott, 2001 [19] focused their attention on norms and mandates such as laws and regulations, beliefs systems, cultural pressures and social comparison processes [20]. It explains the organization based on the social relationship of the group that influences the policy, decision making of the state [20]. Bell argued that, the roles of Institutions in modern democracy cannot be undermined, because as entities, they form such a large part of the political landscape, and because modern governance largely occurs in and through institutions. Institutions also matter because they (or at least actors within them) typically wield power and mobilize institutional resources in political struggles and governance relationships [21]. In particular, attention shifted somewhat away from the state and the formal organisations of government towards a more 'society centered' focus, with an emphasis on the socially embedded nature of pressure group politics, individual political behaviour and informal distributions of power.

The institutional approach argued that more attentions should be paid to the institutional context and to the continuing regulation and thus institutionalizations of unions and the means of their actions [22]. However, the failure of the various institutions to prevent their members as a result of the systemic failure leads to the industrial actions witnessed by the various unions. The importance of this theory is that, it explains the failure of the various institutions in preventing industrial actions and also the socio-political context of the institutions. Institutionalism tends to answer critical question of ceaseless industrial actions by the labour union as it seeks clarification on the political context of maintaining institutional balance and norms. However, the theory is basically criticized for not really explaining the basic tenets or elements of exploitation of the classes of the society that leads to the unionism. It fails to acknowledge the systemic failure arising from the institutions. 
In a Marxist perspective, struggle is inherent in labour-capital relations [23]. The enduring power struggle between workers and employers occurred when workers get disenchanted about their service and the organization can longer boast of the quality of workers' performance, and then there is the existence of emotional hazards in their interests [24]. It rejects the present system as oppressive, exploitative and inequitable and instead desires a new set up in which exploitation and oppression are replaced by a glorious virtue of harmony and cooperation [25].

The theory explains socio-political and economic leading to the formation of the trade union organization. It results from the failure of the bourgeoisies to cater for the welfare of the workers which leads to formation of the labour union as to yearn and aspire for the welfare of the members. The theory explains the class antagonisms and its end are conceived in the circulation of social development when the phase of class identification and resolution of conflicts would unleash glorious human values. The theory best explains the looming industrial actions as a class struggle between the dominant and dominated classes as a result of unjust humiliation, exploitation and oppression of dominant over dominated class. The significance of this theory is that, it exposes the inherent weaknesses and defects of the existing capitalist system and also informs the exploited and the oppressed classes of the workers, peasants and toilers to unite so as to break the chain of slavery and win the whole world [25]. The theory not only explains the reasons for class struggles but also provide a fulcrum for the welfarism of the labour by the exploiters. The theory further explained inequality in the distribution of the proceeds of industry, job-insecurity of the worker, and poor management control strategies that breed grievances which lead to conflict [13]. However, the theory has been criticized for discarding other non-economic factor like religion, morality, emotions; patriotism whose role in politics and administration annealed the subscribers to belief rebelling against the government is against the authority of God on earth. The significant of this theory is that it exposes the hollowness of the present bourgeoisies system that perpetrates social and economic evils for its vested interest [25].

\section{FINDINGS}

The research data was analyzed and presented in this section. Frequency and percentage distribution was utilized to analyze the research data, while the research questions were analyzed using Chi square statistics, Pearson Product Moment Correlation (PPMC) and Multiple Regression analysis.

From the findings, $50.5 \%$ of the respondents were male, while $49.5 \%$ were female. The age distribution revealed that $21.1 \%$ of the respondents were below 20 years, while $49.5 \%$ were within the age ranges of 20 and 30 years, while $29.5 \%$ were above 30 years. On the bases of educational qualification, it was noted that $8.4 \%$ of the respondents were in elementary school, $9.5 \%$ were educated up to the junior high school, and $48.4 \%$ attained high school, while $33.7 \%$ had either diploma, first degree or more higher degree. Also indicated in the table is respondents' employment status and it was noted that $18.9 \%$ were unemployed, $43.2 \%$ were students, $17.9 \%$ were government employees, $10.5 \%$ were private employees, while $9.5 \%$ were into different form of entrepreneur. It was also observed that $20 \%$ of the respondents earn less than $\$ 4,000$ on monthly bases, $28.4 \%$ earn within the ranges of $\$ 4,000$ and $\$ 12,000,11.6 \%$ earn within the ranges of $\$ 12,000$ and $\$ 20,000,8.4 \%$ earn between the ranges of $\$ 20,000$ and $\$ 28,000$, while $31.6 \%$ earn more than $\$ 28,000$ on a monthly bases. This implied that most of the respondents were earning more than $\$ 28,000$ on monthly bases. Lastly, noted was the respondents religion and it was indicated that $22.1 \%$ of the respondents were Muslims, $49.5 \%$ were Pentecostal Christians, $16.8 \%$ were Orthodox Christians, while $11.6 \%$ were engaged in traditional form of religion.

Table-1: Multiple Regression showing the influence of social-demographic factors on perceptions of strike actions on the political economy of Nigeria

\begin{tabular}{|c|c|c|c|c|c|c|c|}
\hline Variables & $\mathbf{B}$ & $\mathbf{T}$ & $\mathbf{R}$ & $\mathbf{P}$ & $\mathbf{R}^{2}$ & Df & $\mathbf{F}$ \\
\hline Gender & -.060 & -.57 & \multirow[t]{4}{*}{.195} & $>.05$ & \multirow[t]{4}{*}{.038} & \multirow[t]{4}{*}{4,90} & \multirow[t]{4}{*}{.886} \\
\hline Age & -.085 & -.71 & & $>.05$ & & & \\
\hline Highest Educational Qualification & -.013 & -.12 & & $>.05$ & & & \\
\hline Monthly Income & -.144 & -1.28 & & $>.05$ & & & \\
\hline
\end{tabular}

Table-1 revealed that gender had no significant influence on the perceptions of strike actions on the political economy of Nigeria $(\beta=-.060, p>.05)$. This implied that both female and male respondents had similar perceptions on the impact of strike actions on the political economy of Nigeria. It was also noted that age had no significant influence on the perceptions of strike actions on the political economy of Nigeria $(\beta=-$ $.085, \mathrm{p}>.05)$. This implied that both young and older ones perceived the impact of strike actions on the political economy of Nigeria. This was similar to the findings on educational qualification and monthly income. And it was such that educational qualification did not predict perceptions of strike actions on the 
political economy of Nigeria $(\beta=-.013, \mathrm{p}>.05)$, while monthly income did not predict perceptions of strike actions on the political economy of Nigeria $(\beta=-.144, p$ $>$.05). It was further observed that the four social- demographic factors considered jointly did not influence the perceptions of strike actions on the political economy of Nigeria $[F(4,90)=0.886, p>.05]$.

\section{CAUSE(S) OF STRIKES}

Research Question 1: What are the factors responsible for strikes in Nigeria?

Table-2: Chi Square summary on statement regarding factors responsible for strikes in Nigeria

\begin{tabular}{|c|c|c|c|c|c|c|}
\hline \multirow[t]{2}{*}{ Items } & \multicolumn{6}{|c|}{ Response } \\
\hline & & SA & $\mathbf{A}$ & D & SD & Total \\
\hline \multirow[t]{2}{*}{ Hike in petroleum price often leads to strike } & $\mathrm{F}$ & 41 & 40 & 13 & 1 & 95 \\
\hline & $\%$ & 43.2 & 42.1 & 13.6 & 1.1 & 100.0 \\
\hline \multirow{2}{*}{$\begin{array}{l}\text { Delay in implementing negotiated agreements between the government and her } \\
\text { employees leads to industrial action }\end{array}$} & $\mathrm{F}$ & 35 & 51 & 8 & 1 & 95 \\
\hline & $\%$ & 36.8 & 53.7 & 8.4 & 1.1 & 100.0 \\
\hline \multirow[t]{2}{*}{ Unfair appraisal system leads to strike } & $\mathrm{F}$ & 24 & 40 & 23 & 8 & 95 \\
\hline & $\%$ & 25.3 & 42.1 & 24.2 & 8.4 & 100.0 \\
\hline \multirow[t]{2}{*}{ Poor working condition leads to industrial action } & $\mathrm{F}$ & 25 & 38 & 23 & 9 & 95 \\
\hline & $\%$ & 26.3 & 40.0 & 24.2 & 9.5 & 100.0 \\
\hline \multirow[t]{2}{*}{ Most industrial actions in Nigeria are partly due to Labour union- interest } & $\mathrm{F}$ & 31 & 38 & 21 & 5 & 95 \\
\hline & $\%$ & 32.6 & 40.0 & 22.1 & 5.3 & 100.0 \\
\hline \multirow[t]{2}{*}{ The inability on the part of management to nip problems in the bud leads to strike } & $\mathrm{F}$ & 27 & 43 & 21 & 4 & 95 \\
\hline & $\%$ & 28.4 & 45.3 & 22.1 & 4.2 & 100.0 \\
\hline \multirow[t]{2}{*}{ Religious crises often leads to industrial actions } & $\mathrm{F}$ & 17 & 23 & 31 & 24 & 95 \\
\hline & $\%$ & 17.9 & 24.2 & 32.6 & 25.3 & 100.0 \\
\hline \multirow[t]{2}{*}{ With inconclusive election, strike is inevitable } & $\mathrm{F}$ & 22 & 26 & 27 & 20 & 95 \\
\hline & $\%$ & 23.2 & 27.4 & 28.4 & 21.1 & 100.0 \\
\hline \multirow[t]{2}{*}{ Strikes serves as a means of bringing the government nearer to the people } & $\mathrm{F}$ & 25 & 29 & 22 & 19 & 95 \\
\hline & $\%$ & 26.3 & 30.5 & 23.2 & 20.0 & 100.0 \\
\hline \multirow{2}{*}{$\begin{array}{l}\text { With industrial action, government hearken to the demands of the populace or } \\
\text { workers }\end{array}$} & $\mathrm{F}$ & 31 & 39 & 21 & 4 & 95 \\
\hline & $\%$ & 32.6 & 41.1 & 22.1 & 4.2 & 100.0 \\
\hline \multirow[t]{2}{*}{ Strikes helps to improve workers welfarism } & $\mathrm{F}$ & 24 & 37 & 22 & 12 & 95 \\
\hline & $\%$ & 25.3 & 38.9 & 23.2 & 12.6 & 100.0 \\
\hline \multirow[t]{2}{*}{ Industrial action serves as a means of check and balances to the government } & $\mathrm{F}$ & 27 & 43 & 18 & 7 & 95 \\
\hline & $\%$ & 28.4 & 45.3 & 18.9 & 7.4 & 100.0 \\
\hline \multirow[t]{2}{*}{ Averaged Total } & $\mathrm{F}$ & 27 & 37 & 21 & 10 & 95 \\
\hline & $\%$ & 28.4 & 38.9 & 22.1 & 10.5 & 100.0 \\
\hline \multirow[t]{3}{*}{ Chi Square } & $\mathrm{X}^{2}$ & & & \multicolumn{3}{|c|}{16.116} \\
\hline & $\mathrm{df}$ & & & \multicolumn{3}{|l|}{3} \\
\hline & $\mathrm{p}$ & & & \multicolumn{3}{|l|}{$<.05$} \\
\hline
\end{tabular}

With regards to the perceived causal factors of strikes in the country, from table 2 above, respondents submitted that hike in petroleum price $(85.3 \%)$; delay in implementing negotiated agreements between the government and her employees' (90.5\%), unfair appraisal system leads to strike $(67.4 \%)$, poor working condition $(66.3 \%)$, Labour Unions' personal interest $(72.6 \%)$, and poor management decisions $(73.7 \%)$ are the major causes of strikes in Nigeria. Majority of the respondents $(73.7 \%)$ perceived that without industrial actions, governments in Nigeria seemed oblivious to the needs and deprivation of the populace and workers. So it serves as a means of getting the attention of government to the dire needs of the people. In this light $(73.7 \%)$ perceived that industrial action serves as a means of checking the excesses of government. However, while $57.9 \%$ of the respondents are of the opinion that religious crises often leads to industrial actions, $42.1 \%$ of the respondents perceived otherwise.
The slim margin differences in the perception of the causes of strikes include inconclusive election result affirmed by $50.6 \%$ affirmed but rebutted by $49.4 \%$ of the respondents. Also, the desire to attract government's attention for patronage was averred to by $56.8 \%$ of the respondents while $43.2 \%$ thought otherwise. The table revealed that the desire for welfarism also incurs strike actions.

Conclusively, it was confirmed by $67.3 \%$ of the respondents that the identified factors were actually the factors responsible for strike actions in Nigeria. This was further ascertained with $\mathrm{X}^{2}$ value of 16.116 , df of 3 and $p$ value that was less than 0.05 level of significant which implied that the observed variation in the distributions were valid for conclusion.

\section{Perceived Implications of Strike Actions}

Strikes are generally political actions taken against employers by employees as a feedback of rejections of the activities of the latter. However given 
the interrelationship that exists between politics and economic status, viability and sustenance of any given institutions or political system, this section seeks to find out if the impact of strikes on the political and economic relations and existence of the State is negligible or otherwise.

Table-3: Chi Square summary on statement regarding the implications of strike actions on Nigeria's political economy

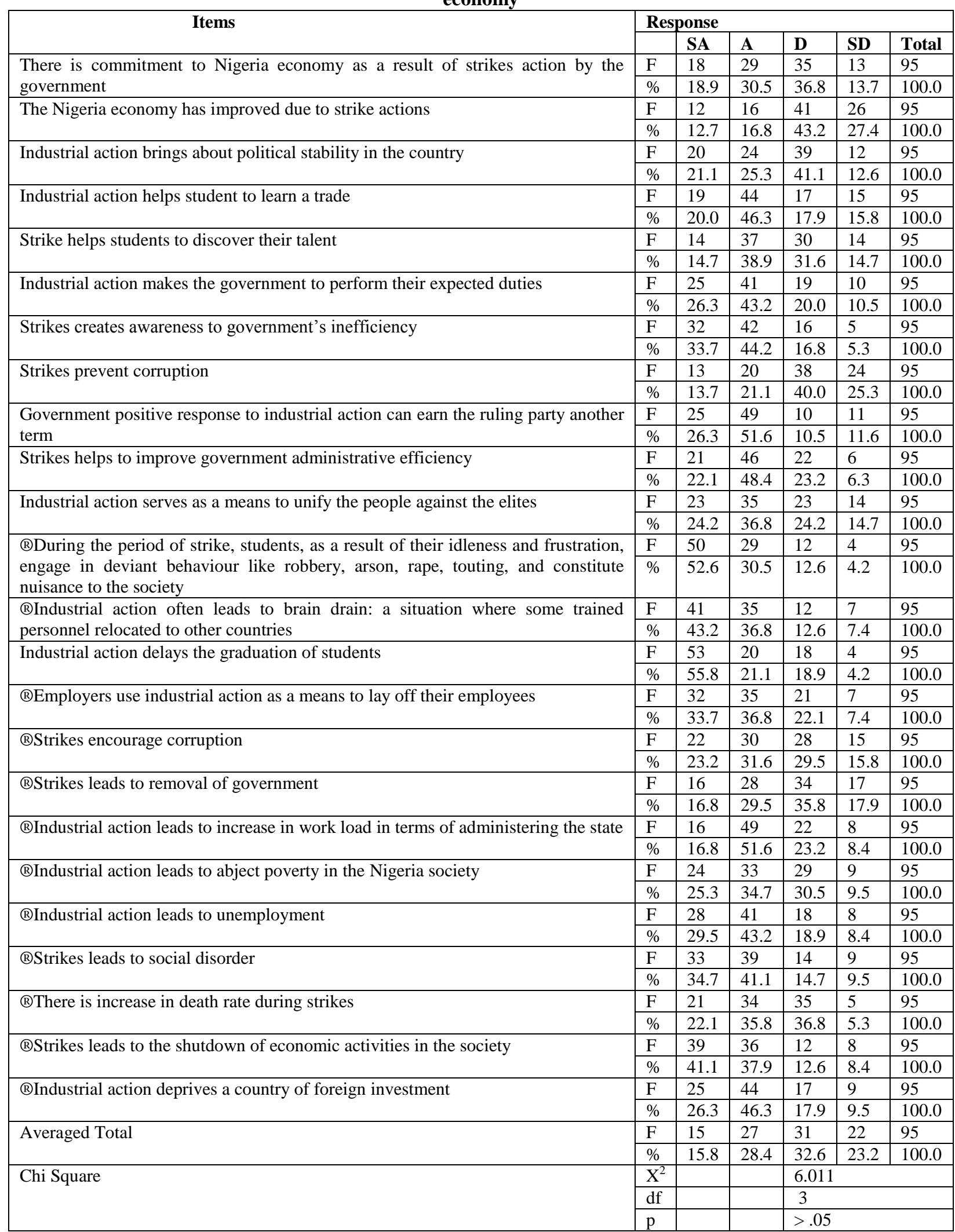


With regards to the positive implications of strike actions, Table-3 shows that $53.6 \%$ of the respondents supported the statement that strike helps students to discover their talents, and engage in productive ventures while the strike lasts. This perception could be due to the later perception by $66.3 \%$ that industrial action helps student to learn a trade, which they can productively engage in later, thereby reducing the level of unemployment in years to come. Also, strike is seen as a means of putting the ruling party of their toes and therefore $53.7 \%$ of the respondents are of the opinion that industrial action does not lead to the removal of government, but rather encourages political stability in the country. Thus, $77.9 \%$ affirmed that Strikes creates awareness to government's inefficiency and in event $69.5 \%$ agreed that industrial action compels the government to perform their expected duties to the citizens in general and workers in particular. Thus, while $70.5 \%$ of the respondents affirmed the statement that strikes helps to improve government administrative efficiency, the political outcome of strikes as affirmed by $77.9 \%$ of the respondents is that government's positive response to industrial action can earn the ruling party another term.

Socially, $83.1 \%$ of the respondents opined that during strikes, especially in the education institutions, students, due to idleness and frustration, engage in deviant behaviour like robbery, arson, rape, touting, and constitute nuisance to the society. Also, $80 \%$ of the respondents submitted that States, institutions and the country loses viable and vital human capital as Industrial action often leads to brain drain, most of whom are difficult to replace or reproduce within a short space of time and resources. Further responses on statements, indicated that $68.4 \%$ of the respondents affirmed the statement that industrial action leads to increase in work load in terms of administering the state. This is expected as non striking workers may be compelled to stand in and perform some of the functions of the striking workers in order to prevent a total systemic breakdown.

Also, $60 \%$ of the respondents supported the statement that given the losses incurred in revenue, industrial action exacerbates the prevalence of abject poverty in the Nigeria society. The perceived loss in revenue could also have contributed to the perception by $72.7 \%$ of the respondents that industrial action leads to unemployment. Therefore, $79 \%$ of the respondents concluded that strikes leads to the shutdown of economic activities in the society, as $72.6 \%$ of the respondents affirmed that industrial action deprives a country of foreign investment. This could be due to the fact investors are often unwilling to bring in foreign capital into an unstable political system. To this end therefore, $70.6 \%$ of the respondents negated the assumption that the Nigeria economy has improved due to strike actions.
However as observed by $84.2 \%$ of the respondents, during strikes, workers establish other means of income, especially agriculture, as coping strategies, therefore implying that is the government that losses in the long run during a strike action. Unfortunately, workers who had found other means of survival other than their jobs may find it difficult to give full commitment to their jobs at the expiration of the industrial action. Also, the private sector, is also affected by strike actions as $79.3 \%$ of the respondents affirmed that industrial actions brings about low sales of goods and services for the entrepreneurs. Hence, $64.2 \%$ affirmed that the poor performance of organizations in Nigeria is traceable to strike actions.

Generally, the summary report indicated that while $44.2 \%$ of the respondents were of the view that the implications of strike actions are positive, 55.8\% perceived it as being negative. From the chi square results, the $\mathrm{X}^{2}$ value of 6.011 , df of 3 was greater than 0.05 level of significant. Therefore, the differences in the responses were not significantly valid for conclusion. Thus, the impact of strike actions involved both positive and negative outcomes on the society and the political economy of the nation. This revealed equivocal responses such that a balance has to be attained in allowance and employment of strike actions, or else, it will result to a destructive tool for the political economy of the nation.

The study also sought to investigate the perceptions on the efficacy of strikes on government policies on wage labour and it was noted that $64.2 \%$ of the respondents agreed that the goals and objectives of labour unions has been clearly defined, stated, and attained as a result of industrial actions. In addition, $66.3 \%$ of the respondents supported the statement that industrial action has helped to stabilize the minimum wage labour. This implied that through strike actions, union leaders and labour unions had been able to achieve their aims and objectives.

Conclusively, it was $65.3 \%$ of the respondents concur with the statement that strike action increases or lead to increase in wage labour, while $34.7 \%$ said otherwise. The $\mathrm{X}^{2}$ value of 24.537 , df of 3 and $p$ value that was less than 0.05 level of significant revealed a valid difference in the observed responses such that it was conclusive. This therefore implied that strike actions affect government policy on wage labour such that it leads to increase in wage labour.

\section{DISCUSSION OF FINDINGS}

With regards to the causes of strikes, the result indicated that $67.3 \%$ of the respondents agreed that strikes occurs due to the aforementioned reasons as stated in table 2 that was analyzed above. The result was in agreement with the work of [26-30]; strikes emanated from policy inconsistencies in the workplace, the breach of memorandum of understanding and the 
wave of globalization which caused inequality in between corporations and workers.

As the study narrows down on the implications of strike actions on the nation and community, finding shows that strikes have multi-faceted outcomes on the nation and society and ultimately puts the economy of the nation is at risk, jeopardize organizational productivity and also affects the workers' means of livelihood and commitment. The findings agrees with the assertions of Mas [29], CBN [31], Fajana [32] and Christensen et al., [33]. The effects of industrial crisis is manifested at both micro and macro levels. At the micro level, the workers lose their purchasing power, and loss of quality human capital formation. Its macro implication involves the exodus of trained personnel to other nations of the world where it is believed that their services would be better rewarded thus resulting to brain drain.

With regards to organizational productivity, the result reveals that during strikes, there is low sale of goods and services for the entrepreneur and that the poor performance of Nigeria's formal and informal sectors are also traceable to the excesses of industrial crisis. This finding is in agreement with the assertion of Mas [29] that from linkage effects, firms that use their products as inputs are affected and their production slows down or comes to a halt. Also, the employer whose workers are on strike loses union services and as a result becomes unable to meet their customers' orders; this invariably affects their returns and profit margin.

However, one of the reasons for the continued use of strikes by labour unions is hemmed on the findings that it positively influences government's policy on wage labour, and has helped in the increment and stability the minimum wage labour, which This finding agrees with the assertion of Kempner [34]; the minimum wage policy of the federal government can be said to be appropriate which needs to be improved in order to keep the real wage relatively satisfactory. Thus, improvements in wage labour over the years have been traced to industrial actions. While labour seems to benefit from strikes in the long run, this study in tandem with Christensen et al., [33] and Fajana [35] perceptions from this study reveals that the adverse effects of industrial crisis portends a great threat on the country as it leads to brain drain which in turn affect the necessary required quality human capital for economic growth and productivity.

Therefore, from the foregoing, it could be deduced that industrial actions poses a lot of threat on the Nigeria society. Though, its occurrence seems to be inevitable because the masses see it as an avenue to unite against the ruling elite in order to project their desires on a particular matter. Thus the larger majority of the population represented in this study sees it as a necessary and effective tool through which their yearnings can be heard and hence be attained.

Essentially, the result of the research shows that, strikes prevent government's arbitrariness; because, strikes serve as a means to check mate the government policies and decisions. However, during the period of strikes as noted by the respondents, a lot of man power, economy opportunities were jeopardized even to the point of brain drain.

This study also reveals the adverse effects of industrial action on the students' as it may go a long way to affect their educational pursuit. And of course, the resultant effects are touting, raping, arson, robbery, and other vices which in turn have far greater negative outcomes on the society. Furthermore, general opinion traces workers' incapacitation and sometimes mortality to the 'no work, no pay' stance of government thereby grossly affects workers whose means of existence emanated from their salary. Beyond them, many who are recipients of services from the striking workers, especially in the health related sectors also suffer mortality, due to strike actions. This was in agreement with the position taken by Nwolise [36] that the implication of strike remains that, government activities were paralyzed, millions of naira was lost during the process and many citizens were killed by malnutrition.

Basically, the impact of strike actions involved both positive and negative outcomes on the society and the political economy of the nation. This study revealed an equivocal response from the respondents' when $42.8 \%$ affirm its negative effects while $55.8 \%$ sees it otherwise. However, in a situation like this, a balance has to be attained for the use of strike actions, or else, it will result to a destructive tool for the political economy of the nation.

\section{CONCLUSION}

In this study, we discuss the implications of industrial actions on the Nigeria organization's productivity and policy actions of the government on wage and labour union. Some of the causes of the industrial actions in Nigeria identified in the study include, hike in price of petroleum, delay in implementation of the negotiated agreements between the government and the employees, unfair appraisal, poor working conditions of the employees, labour union interest, poor welfarism, poor infrastructural development among others. The socio-political and economic implications of the industrial actions cannot be underestimated as it affects all facets and sectors in Nigeria. Given the effects of strike actions on the citizenry and Nigerian organizations, the unions, industries, government and all the stakeholders involve need to take a significant step to limit the prevalence of strike at workplace. 
This can be achieved through deliberate proactive responses of the management and government to the yearnings and aspirations of the employees. Also, there is need for stable labour-management relations with the government and industries that will enhance a good bargaining environment. Also, there is need to improve on minimum wage policy of the government for the employees so as to improve the welfare of the employees. There is need to provide necessary infrastructure, reduce the burden of strike on the populace especially national industrial actions of medical association, and other labour unions which have adverse effects on both the organizations, labour union and the citizenry.

\section{REFERENCES}

1. Ojeifo, S. A. (2014). ASUU Industrial Actions: Between ASUU and Government, Is it an issue of Rightness? Journal of Education and Practice, 5(6), 7-18.

2. International Labour Organization (ILO). (1993). Resolution concerning Statistics of Strikes, Lockouts and Other Action due to Labour Disputes. Available at http://www.ilo.org/global/statistics-anddatabases/standards-andguidelines/resolutionsadopted-by-international-conferences-of-labourstatisticians/WCMS_087544/lang-en/index.htm.

3. Akinwotu, S. A. (2019). The Role of Discursive Constructions in Nigeria's ASUU-FGN Labour Conflict of 2013. The African Journal of Information and Communication (AJIC), 23, 1-18. https://doi.org/10.23962/10539/2753.

4. Ogunbameru, O. A., \& Oribabor P. (2000). Introduction to Industrial Sociology Ile-Ife: OAU Press.

5. Adeogun, A. A. (1980). Strikes: the Law, and the Institutionalization of Labour Protests in Nigeria Indian Journal of Industrial Relations. 16(1), 5672.

6. Dauda, Y. A. (2006). Employment of Independent Arbitrators in the Management of Trade Disputes and Industrial Crises in Nigeria. Nigerian Journal of Labour Law and Industrial Relations, 1(1), 2644.

7. Makosa, B. M. (2007). The history and struggles of ASUU. Ohmy News International.

8. Pohl, N. (2018). Political and Economic Factors influencing strike activity during the recent economic crisis: A study of the Spanish case between 2002 and 2013. Global Labour Journal. 9(1), 19-41.

9. Ubeku, A. K. (1983). Industrial relations in developing countries: The case of Nigeria. London: Palgrave Macmillan. https://doi.org/10.1007/978-1-349-17265-8

10. Wokoma, C. U. (2011). The Effects of Industrial Conflicts and Strikes in Nigeria: A SocioEconomic Analysis. International Journal of Development and Management Review, 6, 32-40.
11. Lee, J., \& Barro, R. (2001). Schooling quality in a cross-section of countries. Econometrica, 68(272):465-488.

12. Pizzorno, A. (1978). Political Exchange and Collective Identity in Industrial Conflict. In The Resurgence of Class Conflict in Western Europe Since 1968, Volume 2: Comparative Analyses, edited by C. Crouch and A. Pizzorno. New York: Holmes \& Meier.

13. Fashoyin, T. (2007). Industrial Relations in Nigeria: Development and Practice Ikeja Longman.

14. Okene, O. V. C. (2008). Collective Bargaining, Strikes and the Quest for Industrial Peace in Nigeria Journal of Labour and Industrial Relations, 2(2): 1-23.

15. Ekankumo, B., \& Konye, I. F. (2014). Managing industrial disputes in the Nigerian teaching hospitals: An empirical analysis. European Journal of Business and Management, 6(19), 152162.

16. Longe, O. (2015). Impact of workplace conflict management on organizational performance: a case of Nigerian manufacturing firm. Journal of Management and Strategy, 6(2), 83-92). https://doi.org/10.5430/jms.v6n2p83

17. David, J., \& Alexander, W. (2018). The Long-Run Effects of Teacher Strikes: Evidence from Argentina. Journal of Labour Economics, University of Chicago, 37(4), 1097-1139.

18. Powell, R. (1991). Absolute and relative gains in international relations theory. The American Political Science Review, 1303-1320.

19. Scott, S., Knapp, M., Henderson, J., \& Maughan, B. (2001). Financial cost of social exclusion: follow up study of antisocial children into adulthood. Bmj, 323(7306), 191.

20. Palmer, D., Dick, B., \& Freiburger, N. (2009). Rigor and relevance in organization studies. Journal of Management Inquiry, 18(4), 265-272.

21. Bell, S. (2017). Institutionalism. Melbourne: Longman.

22. Adam, G., \& Reynaud, J. D. (1978). Conflicts du travail et changement social. Paris: PUF.

23. Hyman, R. (1975). Industrial Relations. A Marxist Introduction. London: Macmillan.

24. Fashoyin, T. (1992). Industrial Relations in Nigeria, 2nd Edition, Ikeja: Longman Ltd.

25. Johari, J. C. (2015). Contemporary Political Theory: New Dimensions, Basic Concepts and Major Trends. New Delhi: Sterling Publisher Private Limited.

26. Fashoyin, T. (2001). Barbados: Fostering economic development through social partnership (No. 993514083402676). International Labour Organization.

27. Aremu, J. A. (2006). Ethical Dimensions of Globalization: Developing Countries' Perspective. Globalization Review, 2(1\&2), 1-29. 
28. Kanfam, B. (2000). The Case of the Company Union. Labor History, 41, 321-350.

29. Mas, A. (2004). Labor Unrest and the Quality of Production: Evidence from the Construction Equipment Resale Market. Industrial Relations/Labor Economics Seminar, Berkeley: Princeton University.

30. Ojiabor, O., \& Faloseyi, M. (2005). NLC Writes Obasanjo Over 49 Sacked Lecturers, Punch, 17(19417), August 24, 8.

31. Central Bank of Nigeria. (2004). Annual Reports and Statements of Accounts.
32. Fajana, S. (2000). Industrial Relations in Nigeria: Theory and Features 2ed, Lagos: Labofin \& Co.

33. Christensen, B. J., Lentz, R., Mortensen, D, T., Neumann, G. R., \& Werwatz, A. (2005). On-theJob Search and the Wage Distribution. Journal of Labour Economics, 23(1), 31-58.

34. Kempner, T. (1980). A Hand Book on Management, USA: Penguins Books Ltd.

35. Fajana, S. (2005). Industrial relations in the oil industry in Nigeria.

36. Nwolise, O. (2003). Wanted: Law Prohibiting Late Salary Payment, The Guardian, September 16. 